\title{
E-banking in Colombia: factors favouring its acceptance, online trust and government support
}

Purpose - This study aims to examine the adoption of e-banking in Colombia, including a comprehensive analysis of consumer trust in this type of transaction and of the impact of the current government policy to promote e-commerce.

Design/ Methodology - An empirical investigation based on the UTAUT2 model collected data from throughout the country to develop 600 online questionnaires.

Findings - The proposed model was validated in that the factors hypothesized to build trust in the use of electronic banking were shown to be significant: trust, performance expectancy and effort expectancy had a positive impact on the use of financial websites in Colombia, while government support did not have a significant impact.

Implications and limitations of the study - The study explains the antecedents to trust, as well as the government support variable, and concludes by producing a model that is highly successful in predicting financial customers' online behaviour.

Practical implications - The results can help Colombia's government and private banks to further develop trust and other conditions necessary for e-banking.

Social implications - Government policies to support the development of ebanking are not viewed favourably by Colombians.

Originality/ Value - This study is one of the first to present empirical findings on the acceptance of e-banking in Latin America; it further presents a model that integrates the most important variables needed for an analysis of the acceptance of e-banking.

Type of paper - Research article

Keywords - E-banking, E-commerce, Adoption, UTAUT, Colombia 


\section{Introduction}

The continuing development of the Internet offers countless innovations in consumer services. In recent decades, other technologies have become closely integrated with information and communication technologies (ICT) because these offer a cost efficient way for businesses to create a competitive advantage in the market and retain their customer base (Bhatt \& Bhatt, 2016; Laukkanen, 2016). Banks have adopted the Internet as a new channel for improving offered services while simultaneously increasing process efficiency, for example, electronic payments, as it provides an online platform that supports many e-commerce transactions (Lee, 2009). E-banking platforms can offer bank customers services that are typically provided in physical branches, such as account status inquiries, transfers and payments to third parties, bank statements, the ability to consult savings and credit simulators, and 24-hour access, among others.

In light of this trend, several studies have found that customers cite a number of reasons for preferring e-banking (Al-sharafi, Arshah, Abu-shanab, Fakhreldin, \& Elayah, 2016; Ayo, Oni, Adewoye, \& Eweoya, 2016; Hui Ling, Islam, Abdul Manaf, \& Wan Mustafa, 2015; Lee, 2009; Tan \& Teo, 2000; Yousafzai, Pallister, \& Foxall, 2003), including transaction speed, lower management costs, greater control over service delivery, shorter wait times, a perception of more customized service, and greater convenience given access to services that is not limited by time or space (Lee, 2009; Montazemi \& Qahri-Saremi, 2015).

Despite its appeal, consumers have been slow to adopt e-banking in some emerging countries (Montazemi \& Qahri-Saremi, 2015). In fact, acceptance of new technologies generally lags behind the pace at which they are introduced in all regions of the world (Katz, Agudelo, Bello, \& \& Rojas, 2015). In regions like Latin America, where there is a significant digital divide (Landau, 2012; Sánchez Torres \& Arroyo-Cañada, 2016), consumers are refraining from using these types of technologically advanced services due in part to a lack of awareness but also due to concerns about security, usability and trustworthiness (Bhatt \& Bhatt, 2016). 
In Colombia, for example, data from the Superintendence of Finance (2016) shows that although both monetary and non-monetary online transactions increased from 951,616,157 in 2012 to 1,905,341,076 in 2015 (comprising 43.97\% of total operations for that year), much scepticism is still apparent when only monetary transactions are considered; these accounted for 313,888,272 operations by 2015 , representing only $13.10 \%$ of total monetary transactions. Other indicators such as the low rate of credit card use (just 10\%) and the high cost of financial services reveal widespread scepticism of e-banking in this country (Rodríguez-Raga \& Riaño Rodríguez, 2016). In addition, government policies and public programmes to develop the digital sector, including e-banking, are limited throughout Latin America (Katz et al., 2015) due to the sector's lack of importance, poor coordination between different sectors, a lack of transparency in the management of those resources devoted to the sector, a lack of trust between the private and public sectors, and the high cost for companies to implement technology services. Therefore, it is important to understand the factors that influence customers' decision to use banking services and how they may be encouraged to engage with them (Ayo et al., 2016).

This study, therefore, intends to analyse the behaviour of e-banking users in Colombia in order to explore the adoption of financial services based on variables drawn from the literature, specifically as follows: first, following the Unified Theory of Acceptance and Use of Technology (UTAUT) model of technology acceptance (Venkatesh, 2003; 2012), test those variables that clients considered most important in their decision to use e-banking; second, examine whether government policies on Internet use are directly and positively related to the acceptance of e-banking; and third, analyse the trust factor in depth because it is a particularly relevant factor in financial transactions (Oliveira, Faria, Thomas, \& Popovič, 2014) and therefore integral to an analysis of the acceptance of e-banking. 


\section{Review of the literature}

\section{Acceptance of e-banking}

Research on the acceptance of online transactions has been guided by theoretical models that explain the acceptance of technologies based on the characteristics of virtual channels, which have been widespread in modern society for only 20 years. Several authors have used theories of technology acceptance to analyse e-banking as well as mobile banking (Afshan \& Sharif, 2016; Oliveira et al., 2014); the main theories are the Theory of Diffusion of Innovations (Rogers, 1995), the Theory of Reasoned Action (TRA) (Fishbein \& Ajzen, 1975), the Social Cognitive Theory (SCT) (Bandura, 1997; Bonera, 2011)), and the Decomposed Theory of Planned Behaviour (DTPB) (Taylor \& Todd, 1995). Research on the acceptance of e-banking (Fishbein \& Ajzen, 1975) has applied two theoretical models that have contributed to analysing the variables most important to this acceptance. The first of these is the Technology Acceptance Model (TAM) (Davis, 1989b), which predicts that an individual's decision about whether to use e-banking is affected by his or her view of the "Perceived Usefulness" and the "Perceived Ease of Use" of electronic banking services (Bukhari et al., 2013). This model is complemented by Davis and Venkatesh and the UTAUT, which subsequently evolved into UTAUT2 (2012) (Venkatesh et al., 2003)). UTAUT2 combines five basic constructs of the eight previous theories: performance expectancy, effort expectancy, social influence, facilitating conditions and trust. The UTAUT and UTAUT2 models have been widely used to study acceptance of e-banking, indicating that performance expectancy, facilitating conditions and trust are important to the acceptance of e-banking (Afshan \& Sharif, 2016; Kurila, Lazuras, \& Ketikidis, 2016; Williams, Michael-D., Rana, Nripendra-P., and Dwivedi, 2015, Hui Ling, Islam, Abdul Manaf, \& Wan Mustafa, 2015).

Variables that have been applied in previous studies of the acceptance of e-banking have been chosen for the first hypothesis of this model.

Effort expectancy for the use of e-banking, defined as the degree of ease with which e-banking can be used (Viswanath Venkatesh, Morris, Davis, \& Davis, 2003), combines the concepts of ease of use of an innovation (Rogers, 1995) and the 
perceived ease of use from the TAM (Davis, 1989a); these have been amply demonstrated to influence the use of e-commerce (Venkatesh, V., Thong, James. Y., $\mathrm{Xu}, 2012$ ) and e-banking (Chong, Ooi, Lin, \& Tan, 2010). Especially in regard to financial transactions, the user expects greater ease online than in branch offices, for example by saving time and minimizing travel. Therefore, the following hypothesis is proposed:

H1: Effort expectancy has a positive impact on the intention to use e-banking in Colombia.

Performance Expectancy refers to the user's beliefs about the benefits brought by using a technology (Viswanath Venkatesh et al., 2003). It combines perceived usefulness (Davis, 1989b), extrinsic motivations (Davis, Bagozzi, \& Warshaw, 1992) and the expectation of results (Bandura, 1977). As one of the most studied and relevant concepts in the acceptance of technological innovation, it has been amply validated with regard to e-commerce and e-banking in that users perceive economic benefits, satisfaction and convenience from e-banking (Oliveira et al., 2014; Zhu, Lee, O’Neal, \& Chen, 2011). Thus, the following hypothesis is proposed:

H2: Performance expectancy has a positive impact on the intention to use e-banking in Colombia.

\section{Government support}

Empirical research about the relation of government support to e-banking acceptance is limited to a few studies of Asian countries (Chong et al., 2010; Tan \& Teo, 2000). However, these studies indicate that it improves acceptance of ebanking, finding that all government policies designed to foster the use of this channel are meaningful; these policies may include less expensive Internet service, web security policies and consumer protection legislation. Efforts to reduce the digital divide and the consequent positive effect on Internet usage have also been extensively studied (Ghobadi \& Ghobadi, 2013; Landau, 2012; White, Gunasekaran, Shea, \& Ariguzo, 2011). A programme spearheaded by the Economic Commission 
on Latin America and the Caribbean (CEPAL) calls for governments in the region to commit to reducing the digital divide in their respective countries (Katz et al., 2015; NU. CEPAL, 2015) and, consequently, to developing policies for online commerce and banking. It is believed that this programme may be contributing to the acceptance of e-banking in Colombia.

Therefore, the following hypothesis is proposed:

H3: Government support for e-banking has a positive impact on the intention to use e-banking in Colombia.

Web trust and its antecedents

Trust is one of the most important variables in a user's decision to online purchase; it is defined as the psychological state of a client's perception of the seller's integrity and benevolence (Zhu et al., 2011). In studies of e-commerce, analysis has concentrated on the characteristics of trust and risk involved in an online purchase (Á. Agudo Peregrina, 2014; Bonera, 2011; Chen \& Dhillon, 2003; Chiu, Chang, Cheng, \& Fang, 2009; Choon Ling, Bin Daud, Hoi Piew, Keoy, \& Hassan, 2011; Escobar-Rodríguez \& Carvajal-Trujillo, 2014; Flavián \& Guinalíu, 2006; H. Kim, Kim, \& Shin, 2009; Mohamed Fadel Bukhari, Ghoneim, Dennis, \& Jamjoom, 2013; Palvia, 2009). This variable carries additional weight in online purchases due to the buyer's heightened sense of uncertainty (Zhu et al., 2011); with regard to e-banking, studies by Afshan \& Sharif (2016) and Chong et al. (2010) show that clients value guarantees by financial institutions regarding online purchases and the handling of confidential information. Therefore, the following hypothesis is proposed:

H4: Perceived trustworthiness of e-banking has a positive impact on the intention to use e-banking in Colombia. 
H5: Perceived trustworthiness of e-banking has a positive impact on the use of $e$ banking in Colombia.

To strengthen this analysis, the antecedents of trust will also be measured. Although there are several models that examine this process (Kaplan \& Nieschwietz, 2003; Zhu et al., 2011), this study has chosen to use the model proposed by D. J. Kim, Ferrin, \& Rao (2008) and subsequently validated in studies of online purchases by Escobar-Rodríguez \& Carvajal-Trujillo (2014), as it offers the most frequently studied constructs: quality of information, protection of privacy and protection of security. The latter two are considered relevant to an examination of e-banking by Yousafzai, Pallister, \& Foxall (2003).

The quality of information variable is very important to the study of the acceptance of web information as it relates to decision-making (Erkan \& Evans, 2016). For the purposes of trust, it can be defined as a user's perception that a website contains complete and accurate information about the products or services of interest (D. J. Kim et al., 2008): the website's information is related to the degree of trust it inspires in the user (Escobar-Rodríguez \& Carvajal-Trujillo, 2014). Therefore, the following hypothesis is proposed:

H6: The quality of information has a positive impact on the perceived trustworthiness of e-banking.

Protection of privacy is the next variable that directly affects web trust; this is defined as the website user's perception that the online transaction is controlled and protected against any unauthorized use. For the purpose of e-banking acceptance, it has been demonstrated that the clients' perception regarding the protection of privacy directly influences their level of confidence (D. J. Kim et al., 2008) in online transactions, since financial information requires high levels of security and control (Yousafzai et al., 2003). This variable has also been the focus of a study of online financial transaction security by Al-sharafi, Arshah, Abushanab, Fakhreldin, \& Elayah (2016) Therefore, the following hypothesis is proposed: 
H7: Protection of privacy has a positive impact on the perceived trustworthiness of ebanking.

The third factor that fosters trust in the web is perceived protection of security, which consists of several features: authentication, protection, verification and encryption (D. J. Kim et al., 2008). When users of a financial website are aware of these factors, they tend to believe that the site will guarantee their security during the online transaction, which serves as an antecedent to trusting the site (EscobarRodríguez \& Carvajal-Trujillo, 2014). In accordance with this and several previous studies that have validated web site trust (Al-sharafi, Arshah, et al., 2016; EscobarRodríguez \& Carvajal-Trujillo, 2014; Flavián \& Guinalíu, 2006; D. J. Kim et al., 2008) the following hypothesis is presented:

H8: Perceived protection of security has a positive impact on the perceived trustworthiness of e-banking.

Intention and use of e-banking

Finally, the UTAUT and UTAUT2 models examine the impact of variables on the intention to use e-banking and, subsequently, on the relation between intention and actual use (Venkatesh et al., 2003; 2012). Therefore, our model concludes by proposing that a user's intention to use e-banking has a direct effect on his or her actual use of e-banking, which may be tested in the following hypothesis:

H9: Intention to use e-banking has a positive impact on the use of e-banking in Colombia.

(Insert figure 1) 


\section{Methodology}

\section{Sample and data collection}

This study focused on collecting the perceptions of e-banking users throughout Colombia by means of an electronic questionnaire, an approach that has been validated in similar studies of e-banking (Á. F. Agudo Peregrina, 2014; EscobarRodríguez \& Carvajal-Trujillo, 2014) including studies set in Portugal (Oliveira et al., 2014), Pakistan (Al-sharafi, Arsha, et al., 2016) and Singapore (Tan \& Teo, 2000). The questionnaire was built and pre-tested with a group of 30 teachers to rule out language and comprehension problems, as recommended by previous studies (Oliveira et al., 2014)). The final questionnaire contained at least three indicators per variable (Annex 1). To facilitate responses, the use of multiple items per construct was followed, and Likert-type scales were used for the questionnaire responses ranging from 1 ("Strongly disagree") to 7 ("Strongly agree") to effectively measure any variables that are not directly observable (Churchill \& Iacobucci, 2004).

The sample was determined using the methodology of stratified sampling with geographic quotas, as this is deemed the most appropriate for studies of large populations that require a representative sample of all members (Hoe, 2008). Thus, the country of Colombia was divided into five geographic zones considering the five most important cities, such that zones 1, 2 and 3 would account for $80 \%$ of the sample, with zones 4 and 5 comprising the other 20\%. Data collection occurred between November 2015 and May 2016. To achieve the sampling goals, a national team was established with coordinators in each of the main cities to manage the dissemination of the questionnaire through an e-mail from universities to ensure greater acceptance. A total of 734 questionnaires were returned, of which 134 were excluded due to inconsistent responses, leaving a final sample of 600 valid questionnaires. The most important characteristic of the sample is that it did not achieve the sampling objectives for areas 4 and 5, as more than $90 \%$ of the sample was concentrated in areas 1, 2 and 3, which include the cities where most of the country's inhabitants (Córdoba-pachón \& Orr, 2009) are located. Although randomly selected, the sample was distributed equally between men and women, 
$70 \%$ of whom were between 18 and 34 years of age, $88 \%$ of whom were university educated, and $79 \%$ of whom earned more than the national average (Table 1); these figures are consistent with the profile of e-banking and financial service users in Colombia (Rodríguez-Raga \& Riaño Rodríguez, 2016).

\section{(Insert Table 1)}

\section{Data analysis and findings}

This study employed a regression analysis of the latent variables with the aid of the SmartPLS 3.0 program; this was based on the optimization of partial least squares (PLS), a multivariate technique for testing structural models that is recommended for exploratory models. This program was chosen, first, because it has been used in previous studies to test the UTAUT and UTAUT2 models for the acceptance of e-banking and e-commerce; second, due to the large number of latent variables that it contains; and finally, because the tested model is an exploratory effort, and it has shown that PLS is the most appropriate for this type of analysis (Escobar-Rodríguez \& Carvajal-Trujillo, 2014; J. F. Hair, Ringle, \& Sarstedt, 2013; Kiwanuka, 2015; Matute Vallejo, Polo Redondo, \& Utrillas Acerete, 2015).

The data analysis was performed in two stages: first, the measurement model was estimated and, second, the validity of the structural model was examined.

\section{(Insert Table 2)}

\subsection{Validation of the model measure}

The measurement instrument was validated through a test analysis to determine first the convergent and discriminant validity of the constructs and, second, the reliability of each item. The convergent validity of each construct was acceptable, as all had loadings higher than 0.505 (J. F. J. Hair, Hult, Ringle, \& Sarstedt, 2014). Each item's individual reliability was measured by the correlations of its loadings with every variable; table * shows that the loadings for each indicator were significant, and all are validated. The internal consistency for all indicators in 
relation to their corresponding variables was measured using Dillon-Goldstein's test; this is known as the composite reliability coefficient, and all values were greater than the minimum acceptable level of 0.70 (Gefen, Straub, \& Boudreau, 2000). Cronbach's alpha test was also applied, and it also obtained values higher than the 0.7 minimum needed for confirmation (Churchill \& Iacobucci, 2004). Finally, convergent validity was again analysed taking variance into account, i.e., that indicators and their construct have similar variance, which should be greater than 0.50 of the variability explained by the indicators (Fornell \& Larcker, 1981)(Table 2). Discriminant validity was tested by comparing each variable's AVE with the correlation of each construct of each variable squared; the values obtained from the square root of the AVE were greater than the constructs, showing that each variable was more closely associated with its own items than with those of other variables (Fornell \& Larcker, 1981) (Table 3).

The discriminant validity was verified by comparing the value of the average variance extracted (AVE) of each variable with the correlation of each construct of every variable squared. The values obtained from the square root of the AVE were higher than those of the constructs, thus indicating that each variable was related more strongly with its own items than with those of other variables (Fornell \& Larcker, 1981) (Table 4).

\section{(Insert Table 3)}

\section{(Insert Table 4)}

\subsection{Validation of the structural model}

Turning to the structural model, a re-sampling was conducted using the bootstrapping technique. A test of the significance of the model's parameters was performed using 1,000 sub-samples from the study data; this confirmed that the model had fulfilled its predictive capacity by obtaining $R$ squared values greater than 0.10 for the three variables explained (J. F. J. Hair et al., 2014). The hypotheses were tested as follows. Hypothesis $1(\mathrm{H} 1: \mathrm{B}=-0.182)$ was not significant, as users do not perceive effort expectancy with regard to the use of e-banking. Hypothesis 2 
$(\mathrm{H} 2$ : $\mathrm{B}=0.679)$ was significant, showing that performance expectancy is highly influential in users' intention to use e-banking. Hypothesis $3(\mathrm{H} 3: \mathrm{B}=0.019)$ was not significant, indicating that government support does affect the intention to use e-banking. Hypothesis $4(\mathrm{H} 4: \mathrm{B}=0.301)$ was significant, showing that perceived trustworthiness positively affects the intention to use e-banking. Hypothesis 5 (H5: $\mathrm{B}=0.181$ ) was significant, showing that perceived trustworthiness positively affects the actual use of e-banking. Hypothesis 6 (H6: $B=0.506)$ was significant, finding that the perceived quality of information positively affects the perception of trust. Hypothesis 7 (H7 7: B=0.054) was significant, showing that perceived privacy in banking websites positively affects the perception of their trustworthiness. Hypothesis 8 (H8: $\mathrm{B}=0.408$ ) was significant, indicating that the perceived security of financial websites positively affects perceptions of the bank's trustworthiness. Hypothesis 9 (H9: $\mathrm{B}=0.326)$ was significant, confirming that intention to use directly and positively affects the actual use of e-banking in Colombia (Table 5).

\section{(Insert figure 2)}

\section{(Insert Table 5)}

\section{Discussion}

This study aimed to describe the variables that influence the acceptance of ebanking in Colombia. More specifically, the study sought to test the relationships between the main variables that influence the acceptance of e-banking (Afshan \& Sharif, 2016; Kurila, Lazuras, \& Ketikidis, 2016; Williams, Michael-D., Rana, Nripendra-P., and Dwivedi, 2015, Hui Ling, Islam, Abdul Manaf, \& Wan Mustafa, 2015). First, the effort expectancy variable was found to have no significant impact on the intention to use e-banking in Colombia. This result contradicts the findings of other studies on the acceptance of e-banking (Afshan \& Sharif, 2016; Oliveira et al., 2014). This unexpected finding may indicate that users have already developed expertise in managing e-banking operations, rendering this variable insignificant; however, the negative result could also indicate precisely the opposite, denoting a 
lack of user experience and the novelty of Internet access in this country that leads to doubts and negative expectations about the use of e-banking. The results of the performance expectancy variable are consistent with the theory (Oliveira et al., 2014; Yousafzai et al., 2003) and indicate that users in Colombia have high expectations regarding the benefits that e-banking use will bring; this finding supports claims that this construct is essential to the acceptance of e-banking.

Users of e-banking in Colombia did not feel that government support of Internet use had any effect on their intention to use online banking; these results differ from other studies that found this variable to be highly significant, especially in Asian countries (Chong et al., 2010; Tan \& Teo, 2000). This finding merits detailed analysis, as the government has implemented a series of policies over the past decade focusing on developing the digital sector. These policies may have been ineffective with regard to e-banking, or users may consider them irrelevant to their decision to use these services, perhaps because banking is a private sector activity that has distanced itself from these policies in users' eyes.

With regard to perceived trustworthiness, the study validates the strong influence of this factor on both the intention to use and the actual use of e-banking, demonstrating that users place high importance on a number of security features and that these bolster users' confidence in banking websites (Chong et al., 2010; Yousafzai et al., 2003).

More detailed analysis reveals that clients consider certain features of a website to be essential. The first is the quality of information: it is important that a client is able to find a webpage containing all information needed for banking, including processes, transactions, policies, customer service and resolution of problems. Since this is highly valued in the Colombian case, it may be deduced that users perceive the country's e-banking sites to offer high quality information.

Perceived privacy is the next important aspect for developing a perception of ebanking as trustworthy. This factor was shown to be significant, but given the context of distrust in online transactions in Colombia (Tavera-Mesías, SánchezGiraldo, \& Ballesteros-Díaz, 2011), especially when personal information or large financial sums are involved, Colombians may fear that their financial information, bank accounts and balances could be vulnerable to hacking or theft. It is believed the approval of e-banking in Colombia is tied to improvements in website security, 
as well as to the fact that banks have taken steps to raise clients' awareness about the proper use of their confidential information

Finally, in connection with the previous two factors, perceived security is also highly valued by Colombian users as contributing significantly to their perception of websites' trustworthiness. This result stems from the development and adoption of electronic encryption, and the adaptation of high-level global security for online transactions and highly secure personal access by all financial institutions.

As a final contribution to this line of research, this study is one of the first to analyse the factors that affect the acceptance of e-banking in Latin America, focusing on the Colombian case because of the country's current leading role in the development of online services and commerce (Katz et al., 2015; NU. CEPAL, 2015). These results reinforce the importance of key variables in the use of ebanking. Further, they support the critical role played by the antecedents of trust, which is of great importance to users of virtual services. Finally, the government support variable is found to be not significant, so it is not possible to determine its direct impact on the acceptance of e-banking.

\section{Implications, limitations and future research directions}

This study is one of the first to present empirical findings on the acceptance of ebanking in Latin America. It presents a model that integrates the most important variables for an analysis of the acceptance of e-banking, especially in countries or regions where development is recent, making an original contribution by explaining the antecedents of trust as well as the government support variable. Further, this model can be used to predict the online behaviour of financial clients. For the business sector (in this case, financial institutions), this study determines which variables are most important to their clients and analyses their needs and behaviour with regard to the use of financial websites.

Considering Colombia's government, the study examined whether citizens believe that government policies have a positive impact on the use of e-banking. This study found that citizens do not believe that government support favours online 
commerce, and the reasons behind this result should be examined, as it has been national policy to promote Internet use. One would expect to find a positive impact from this policy on the acceptance of e-banking, particularly as not all citizens have access to financial services and banking due to social gaps, such as education and economic level (Landau, 2012).

The limitation of this study is that despite its high degree of prediction, the proposed model may be missing other variables that would improve the description of the acceptance of e-banking. Other authors (Afshan \& Sharif, 2016) analyse different antecedents for trust and integrate other technological constructs, allowing them to analyse differences between men and women to determine the moderating effect of gender (Oliveira et al., 2014). Additionally, the inclusion of the government support variable did not produce the expected result, leaving doubts about its direct or indirect influence on e-banking; thus, further studies are required in similar countries to confirm the result. It is proposed that further studies apply this model in other countries in the region to test for possible differences that can contribute to improving online financial services in Latin America.

\section{References}

Afshan, S., \& Sharif, A. (2016), "Acceptance of mobile banking framework in Pakistan", Telematics and Informatics, Vol. 33 No. 2, pp. 370-387.

Agudo Peregrina, Á. (2014), "Análisis de los factores de adopción de comercio electrónico en segmentos de consumidores finales. Aplicación al caso español", Universidad Politécnica de Madrid, España.

Al-sharafi, M. A., Arshah, R. A., Abu-shanab, E., Fakhreldin, M., \& Elayah, N. (2016), "The Effect of Security and Privacy Perceptions on Customers ' Trust to Accept Internet Banking Services?: An Extension of TAM Literature Review", Journal of Engineering and Applied Sciences, Vol. 11 No.3, pp. 545-552.

Ayo, C. k., Oni, A. A., Adewoye, O. J., \& Eweoya, I. O. (2016), "E-banking users' behaviour: e-service quality, attitude, and customer satisfaction", International Journal of Bank Marketing, Vol. 34 No.3, pp. 347-367.

Bandura, A. (1977), "Self-efficacy: toward a unifying theory of behavioral change", Psychological Review, Vol. 84 No. 2, pp. 191-215.

Bhatt, A., \& Bhatt, S. (2016), "Factors Affecting Customers Adoption of Mobile Banking Services", The Journal of Internet Banking and Commerce, Vol. 21, pp.161.

Bonera, M. (2011), "The propensity of e-commerce usage: the influencing variables", Management Research Review, Vol. 34 No.7, pp. 821-837. 
Bukhari, S. M. F., Ghoneim, A., Dennis, C., \& Jamjoom, B. (2013), "The antecedents of travellers' e-satisfaction and intention to buy airline tickets online: A conceptual model", Journal of Enterprise Information Management, Vol. 26 No. 6, pp. 624-641.

Chen, S. C., \& Dhillon, G. S. (2003), "Interpreting Dimensions of Consumer Trust in E-commerce", Information Technology and Management, Vol. 4, pp. 303-318.

Chiu, C.-M., Chang, C.-C., Cheng, H.-L., \& Fang, Y.-H. (2009), "Determinants of customer repurchase intention in online shopping", Online Information Review, Vol. 33 No. 4, pp. 761-784.

Chong, A. Y.-L., Ooi, K.-B., Lin, B., \& Tan, B.-I. (2010), "Online banking adoption: an empirical analysis", International Journal of Bank Marketing, Vol. 28 No. 4, pp. 267-287.

Choon Ling, K., Bin Daud, D., Hoi Piew, T., Keoy, K. H., \& Hassan, P. (2011), "Perceived Risk, Perceived Technology, Online Trust for the Online Purchase Intention in Malaysia", International Journal of Business and Management, Vol. 6 No. 6, pp. 167-182.

Churchill, G. A., \& Iacobucci, D. (2004), Marketing Research: Methodological Foundations. Structural Equation Modeling, Vol. 4.

Córdoba-pachón, J., \& Orr, K. (2009). "Three patterns to understand e-government: the case of Colombia", International Journal of Public Sector Management, vol. 22 No. 6, pp. 532-554.

Davis, F. D. (1989), "Perceived Usefulness, Perceived Ease of Use, and User Acceptance of Information Technology", MIS Quarterly, Vol. 13 No. 3, pp. 319.

Davis, F. D., Bagozzi, R. P., \& Warshaw, P. R. (1992), "Extrinsic and Intrinsic Motivation to Use Computers in the Workplace", Business, Vol. 22, pp. 11111132.

Erkan, I., \& Evans, C. (2016), "The influence of eWOM in social media on consumers' purchase intentions: An extended approach to information adoption", Computers in Human Behavior, Vol. 61, pp. 47-55.

Escobar-Rodríguez, T., \& Carvajal-Trujillo, E. (2014), "Online purchasing tickets for low cost carriers: An application of the unified theory of acceptance and use of technology (UTAUT) model", Tourism Management, Vol. 43, pp. 70-88.

Fishbein, M., \& Ajzen, I. (1975), Belief, Attitude, Intention, and Behavior: An Introduction to Theory and Research, Reading, MA: Addison-Wesley.

Flavián, C., \& Guinalíu, M. (2006), "Consumer trust, perceived security and privacy policy: Three basic elements of loyalty to a web site", Industrial Management \& Data Systems, Vol. 106, No.5, pp. 601-620.

Fornell, C., \& Larcker, D. F. (1981), "Evaluating Structural Equation Models with Unobservable Variables and Measurement Error", Journal of Marketing Research, Vol. 18 No.1, pp. 39.

Gefen, D., Straub, D. W., \& Boudreau, M.-C. (2000), "Structural Equation Modeling and Regression?: Guidelines for Research Practice", Communications of the Association for Information Systems, Vol. 4(October), pp. 7.

Ghobadi, S., \& Ghobadi, Z. (2013), "Digital divide and interrelated access gaps: A cognitive investigation", Proceedings of the 21st European Conference on Information Systems, 2013, pp. 1-13.

Hair, J. F., Ringle, C. M., \& Sarstedt, M. (2013). Partial Least Squares Structural Equation Modeling: Rigorous Applications, Better Results and Higher Acceptance. Long Range Planning, 46(1-2), 1-12. 
Hair, J. F. J., Hult, G. T. M., Ringle, C., \& Sarstedt, M. (2014), "A Primer on Partial Least Squares Structural Equation Modeling (PLS-SEM)", Long Range Planning, Vol. 46.

Hoe, S. L. (2008). Issues and procedures in adopting structural equation modeling technique. Journal of Applied Quantitative Methods, 3(1), 76-83.

Hui Ling, C., Islam, M. A., Abdul Manaf, A. H., \& Wan Mustafa, W. M. (2015). Users Satisfaction Towards Online Banking in Malaysia. International Business Management. Vol. 9 No.1, pp. 15-27.

Kaplan, S. E., \& Nieschwietz, R. J. (2003). A Web assurance services model of trust for B2C e-commerce. International Journal of Accounting Information Systems, 4(2), 95-114.

Kaplan, S. E., \& Nieschwietz, R. J. (2003). A Web assurance services model of trust for B2C e-commerce. International Journal of Accounting Information Systems, 4(2), 95-114.

Katz, R., Agudelo, M., Bello, P., \& \& Rojas, E.-F. (2015). El ecosistema y la economía digital en América Latina, F. Telefonica, Ed. Ariel, Barcelona.

Kim, D. J., Ferrin, D. L., \& Rao, H. R. (2008), "A trust-based consumer decisionmaking model in electronic commerce: The role of trust, perceived risk, and their antecedents", Decision Support Systems, Vol. 44 No.2, 544-564.

Kim, H., Kim, T., \& Shin, S. W. (2009), "Modeling roles of subjective norms and eTrust in customers' acceptance of airline B2C eCommerce websites", Tourism Management, Vol. 30 No. 2, pp. 266-277.

Kiwanuka, A. (2015), "Acceptance Process?: The Missing Link between UTAUT and Diffusion of Innovation Theory", American Journal of Information Systems, Vol. 3 No.2, pp. 40-44.

Kurila, J., Lazuras, L., \& Ketikidis, P. H. (2016), "Message framing and acceptance of branchless banking technology", Electronic Commerce Research and Applications, Vol. 17, pp. 12-18.

Landau, L. (2012), Estado de la Banda Ancha en América Latina y el Caribe, Informe del Observatorio Regional de Banda Ancha (ORBA). CEPAL.

Laukkanen, T. (2016), "Consumer adoption versus rejection decisions in seemingly similar service innovations: The case of the Internet and mobile banking", Journal of Business Research, Vol. 69 No.7, pp. 2432-2439.

Lee, M.-C. (2009), "Factors influencing the adoption of internet banking: An integration of TAM and TPB with perceived risk and perceived benefit" Electronic Commerce Research and Applications, Vol. 8 No.3, pp. 130-141.

Manaf, A. H., \& Wan Mustafa, W. M. (2015), "Users Satisfaction Towards Online Banking in Malaysia", International Business Management, Vol. 9 No. 1, pp. 1527

Matute Vallejo, J., Polo Redondo, Y., \& Utrillas Acerete, A. (2015), "Las características del boca-oído electrónico y su influencia en la intención de recompra online", Revista Europea de Direccion Y Economia de La Empresa, Vol. 24 No. 2, pp. 61-75.

Mohamed Fadel Bukhari, S., Ghoneim, A., Dennis, C., \& Jamjoom, B. (2013), "The antecedents of travellers' e-satisfaction and intention to buy airline tickets online", Journal of Enterprise Information Management, Vol.26 No. 6, pp. 624641.

Montazemi, A. R., \& Qahri-Saremi, H. (2015), "Factors affecting adoption of online banking: A meta-analytic structural equation modeling study", Information \& 
Management, Vol. 52 No. 2, pp. 210-226.

NU. CEPAL. (2015). La nueva revolucion digital. De la Internet del consumo a la Internet de la producción, 100. Retrieved from:

http://www.antel.com.uy/wps/wcm/connect/ab01f180496e14fe9d69fdaf68 90d810/S1500587_es.pdf?MOD=AJPERES

Oliveira, T., Faria, M., Thomas, M. A., \& Popovič, A. (2014). Extending the understanding of mobile banking adoption: When UTAUT meets TTF and ITM. International Journal of Information Management, Vol. 34 No. 5, pp. 689-703.

Palvia, P. (2009), "The role of trust in e-commerce relational exchange: A unified model", Information and Management, Vol. 46 No. 4, pp. 213-220.

Rodríguez-Raga, S., \& Riaño Rodríguez, F. F. (2016), "Determinantes del acceso a los productos financieros en los hogares colombianos", Estudios Gerenciales, Vol. 32 No. 138, pp. 14-24.

Rogers, E. M. (1995). Diffusion of innovations. New York.

Sánchez Torres, J. A., \& Arroyo-Cañada, F.-J. (2016). "Diferencias de la adopción del comercio electrónico entre países", Suma de Negocios, Vol. 7 No. 16, pp. 141150.

Superintendencia Financiera. (2016), Informe de operaciones: Segundo semestre de 2015, No. 1215, Superintendencia Financiera de Colombia. Colombia

Tan, M., \& Teo, T. S. H. (2000), "Factors Influencing the Adoption of Internet Banking", Journal of the Association for Information Systems, Vol. 1 No. 1, pp. 144.

Tavera-Mesías, J. F., Sánchez-Giraldo, J. C., \& Ballesteros-Díaz, B. (2011).

"Aceptación del e-commerce en Colombia: Un estudio para la ciudad de Medellín", Revista de La Facultad de Ciencias Económicas de La Universidad Militar Nueva Granada. Rev.fac.cienc.econ,Vol. 19 No. 2, pp. 9-23.

Taylor, S., \& Todd, P. A. (1995). "Understanding information technology usage: A test of competing models", Information Systems Research, Vol. 6 No. 2, pp. 144-176.

Venkatesh, V., Thong, James. Y., Xu, X. (2012), "Consumer Acceptance and Use of Information Technology: Extending the Unified Theory of Acceptance and Use of Technology", MIS Quarterly, Vol. 36 No. 1, pp. 157-178

Venkatesh, V., Morris, M., Davis, G., \& Davis, F. (2003), "User Acceptance of information Technology: Toward a Unified View", MIS Quarterly, Vol. 27 No. 3, pp. 425-478.

White, D. S., Gunasekaran, A., Shea, T. P., \& Ariguzo, G. C. (2011), "Mapping the global digital divide", International Journal of Business Information Systems, Vol. 7 No. 2, pp. 207.

Williams, Michael-D., Rana, Nripendra-P., and Dwivedi, Y.-K. (2015), "The unified theory of acceptance and use of technology (UTAUT): a literature review", Journal of Enterprise Information Management, Vol. 28 No. 3, pp. 433-488.

Yousafzai, S. Y., Pallister, J. G., \& Foxall, G. R. (2003), "A proposed model of e-trust for electronic banking", Technovation, Vol. 23 No.11, pp. 847-860.

Zhu, D. S., Lee, Z. C., O'Neal, G. S., \& Chen, Y. H. (2011), "Mr. Risk! Please trust me: Trust antecedents that increase online consumer purchase intention", Journal of Internet Banking and Commerce, Vol. 16 No. 3, pp. 1. 
Annex 1

Questionnaire

\begin{tabular}{|c|c|c|}
\hline Construct & Item & Source \\
\hline$(\mathrm{AU})$ & $\begin{array}{l}\text { AU1 ¿How many times during the last year have you } \\
\text { used your bank's services online? }\end{array}$ & $\begin{array}{l}\text { Venkatesh (2012) } \\
\text { Escobar \& Carvajal } \\
\text { (2014) }\end{array}$ \\
\hline$(\mathrm{BI})$ & $\begin{array}{l}\text { BI1. I intend to use online banking if time and costs are } \\
\text { reasonable for me. } \\
\text { BI2. In the future I will use online banking. } \\
\text { BI3. I intend to use online banking in the future. }\end{array}$ & Venkatesh (2012) \\
\hline$(\mathrm{PE})$ & $\begin{array}{l}\text { PE1. Overall I think online banking makes it easier for } \\
\text { me to do my daily financial transactions. } \\
\text { PE2. Overall I think online banking is more useful than } \\
\text { other traditional forms of banking (Physical office). } \\
\text { PE3. Overall I think online banking easier } \\
\text { communications with my bank. }\end{array}$ & $\begin{array}{l}\text { San Martín \& Herrero } \\
\quad \text { (2012) } \\
\text { Venkatesh }(2012)\end{array}$ \\
\hline (EE) & $\begin{array}{l}\text { EE1 Overall I think online banking is easy and simple to } \\
\text { use. } \\
\text { EE2. Overall I think online banking is clear and } \\
\text { understandable. } \\
\text { EE3. Overall I think online banking allows different } \\
\text { types of operations being easy to learn and } \\
\text { remember their use. }\end{array}$ & $\begin{array}{l}\text { San Martín \& Herrero } \\
\text { (2012) } \\
\text { Venkatesh (2012) } \\
\text { Escobar \& Carvajal } \\
\text { (2014) }\end{array}$ \\
\hline (GS) & $\begin{array}{l}\text { GS1. Overall I think the government has policies that } \\
\text { promote the use of internet and e-commerce. } \\
\text { GS2. Overall I think the government is promoting the } \\
\text { development of online banking. } \\
\text { GS3. Overall I think the government has a favorable } \\
\text { legislation to use online banking. }\end{array}$ & Chong et al., (2010) \\
\hline (PT) & $\begin{array}{l}\text { PT1. Overall I think online banking is trusted. } \\
\text { PT2. Overall I think online banking fulfills its promises } \\
\text { and commitments. } \\
\text { PT3. Overall I think that online banking is reliable for } \\
\text { electronic procedures offered. }\end{array}$ & $\begin{array}{l}\text { Agudo-Peregrina } \\
\text { (2014) } \\
\text { Escobar \& Carvajal } \\
\quad(2014)\end{array}$ \\
\hline (IQ) & $\begin{array}{l}\text { IQ1. Overall I think, online banking informs me fully } \\
\text { about the transaction and its final check. } \\
\text { IQ2. Overall I consider that online banking is easy to }\end{array}$ & $\begin{array}{l}\text { Escobar \& Carvajal } \\
\quad(2014)\end{array}$ \\
\hline
\end{tabular}




\begin{tabular}{|c|c|c|}
\hline & $\begin{array}{l}\text { navigate and content lets me know so detailed and } \\
\text { accurate all the information. } \\
\text { IQ3. Overall I consider that online banking gives me } \\
\text { true and updated information on their products or } \\
\text { services. }\end{array}$ & \\
\hline (PS) & $\begin{array}{l}\text { PS1. I believe that online banks have a secure web for } \\
\text { electronic transactions. } \\
\text { PS2. I consider that online banks guarantee on its } \\
\text { website that throughout the process is not } \\
\text { interrupted or transaction information allowing } \\
\text { successfully finish is not lost. } \\
\text { PS3 I consider that online banks keep and handle my } \\
\text { personal information safely. }\end{array}$ & $\begin{array}{l}\text { Escobar \& Carvajal } \\
\qquad(2014)\end{array}$ \\
\hline$(\mathrm{PP})$ & $\begin{array}{l}\text { PP1. I am concerned that online banks will use my } \\
\text { personal data for their business interests without } \\
\text { my permission. } \\
\text { PP2. I am concerned that the online banks will exchange } \\
\text { my personal data with others with my } \\
\text { authorization. } \\
\text { PP3. I am concerned that unauthorized persons (i.e. } \\
\text { hackers) have access to my personal information. }\end{array}$ & $\begin{array}{c}\text { Escobar \& Carvajal } \\
\text { (2014) }\end{array}$ \\
\hline
\end{tabular}


Table 1

Sample characteristics

\begin{tabular}{|l|l|l|}
\hline \multicolumn{2}{|c|}{ Demographic profile } & \multicolumn{1}{|c|}{ Internet and e-commerce acceptance profile } \\
\hline Gender: & Age: & Experience with Internet use: \\
Wen 54\% & $18-34$ years 70\% & \\
& $35-44$ years 20\% & More than 10 years 55\% \\
& $45-55$ years 10\% & Between 5 - 10 years 45\% \\
\hline Educational level: & Economic level & Location: \\
Primary 0\% & (income 1 ): & Zone 1 \\
High School 12\% & Very low 3\% & (Antioquia, Caldas, Quindío, Risaralda) 25\% \\
Technical degree & Low 18\% & Zone 2 \\
$26 \%$ & Moderate 45\% & (Boyacá, Cundinamarca, Bogotá) 42\% \\
University 42\% & Upper-middle & Zone 3 \\
Post-graduate 20\% & $20 \%$ & (Cauca, Valle del Cauca) 27\% \\
& High 12\% & Zone 4 \\
& Very high 2\% & (Atlantic, Bolivar, Cesar, San Andrés, Magdalena, \\
\hline Marital status: & Size of & Santander) 6\% \\
Single, & household: & Zone 5 \\
separated, widowed & 1 person 9\% & (Arauca, Caquetá, Huila Meta, Nariño, Tolima, \\
$63 \%$ & 2 people 18\% & Vaupés) 1\% \\
Married, & 3 people 28\% & \\
Free union 37\% & 4 people 55\% & \\
5 people 16\% & \\
\hline
\end{tabular}

${ }^{1}$ Adapted from the classification used in Colombia according to public sources 
Table 2

Loads of the indicators

\begin{tabular}{|c|c|c|}
\hline \multicolumn{3}{|c|}{ Non-buyers } \\
\hline Indicator & Load & t-value* \\
\hline$(\mathrm{B} \mid 24)<-$ intention to use e-banking & 0.976 & 357,981 \\
\hline$(\mathrm{B} \mid 34)<-$ intention to use e-banking & 0.974 & 339,876 \\
\hline (EE14) < - effort expectancy & 0.969 & 270,843 \\
\hline (EE14) < - effort expectancy & 0.962 & 213,590 \\
\hline (EE14) < - effort expectancy & 0.963 & 233,034 \\
\hline (IQ14) < - quality of information & 0.949 & 141,041 \\
\hline$($ IQ24) < - quality of information & 0.960 & 226,804 \\
\hline (IQ34) < - quality of information & 0.948 & 109,565 \\
\hline (PE14) < - performance expectancy & 0.952 & 172,376 \\
\hline (PE24) <- performance expectancy & 0.949 & 162,282 \\
\hline (PE34) <- performance expectancy & 0.911 & 62,156 \\
\hline (PP14) < - perceived privacy & 0.892 & 83,988 \\
\hline$($ PP24) $<-$ perceived privacy & 0.881 & 63,207 \\
\hline (PP34) <- perceived privacy & 0.843 & 51,748 \\
\hline (PS14) <- perceived security & 0.936 & 136,743 \\
\hline (PS24) < - perceived security & 0.935 & 136,360 \\
\hline (PS34) < - perceived security & 0.904 & 87,439 \\
\hline (PT14) $<-$ trust & 0.967 & 246,806 \\
\hline$(\mathrm{PT} 24)<-$ trust & 0.960 & 213,168 \\
\hline$(\mathrm{PT} 34)<-$ trust & 0.965 & 210,118 \\
\hline B14 <- intention to use e-banking & 0.946 & 122,314 \\
\hline GS1 <- government support & 0.926 & 104,844 \\
\hline GS2 <- government support & 0.957 & 198,713 \\
\hline GS3 < - government support & 0.888 & 55,464 \\
\hline
\end{tabular}

All items had significance with $p$-value $<0.001$.

Table 3

Convergent validity of indicators

\begin{tabular}{|l|l|l|l|}
\hline \multicolumn{4}{|c|}{ Non-buyers } \\
\hline \multicolumn{1}{|c|}{ Variables } & $\begin{array}{l}\text { Cronbach's } \\
\text { Alpha }\end{array}$ & $\begin{array}{l}\text { Composite } \\
\text { reliability }\end{array}$ & $\begin{array}{l}\text { Average } \\
\text { Variance } \\
\text { Extracted (AVE) }\end{array}$ \\
\hline Quality of information & 0.949 & 0.967 & 0.907 \\
\hline Trust & 0.962 & 0.975 & 0.929 \\
\hline Performance expectancy & 0.931 & 0.956 & 0.879 \\
\hline Effort expectancy & 0.963 & 0.976 & 0.931 \\
\hline
\end{tabular}




\begin{tabular}{|l|l|l|l|}
\hline Intention to use e-banking & 0.963 & 0.976 & 0.932 \\
\hline Perceived privacy & 0.843 & 0.905 & 0.761 \\
\hline Perceived security & 0.916 & 0.947 & 0.856 \\
\hline Government support & 0.915 & 0.946 & 0.854 \\
\hline
\end{tabular}

Table 4

Discriminant validity of indicators - Fornell \& Larcker test

\begin{tabular}{|l|l|l|l|r|r|l|l|l|l|}
\hline & $\begin{array}{l}\text { Quality of } \\
\text { information }\end{array}$ & Trust & $\begin{array}{r}\text { Performance } \\
\text { expectancy }\end{array}$ & $\begin{array}{r}\text { Effort } \\
\text { expecta } \\
\text { ncy }\end{array}$ & $\begin{array}{r}\text { Intentio } \\
\text { nto use } \\
\text { e- } \\
\text { banking }\end{array}$ & $\begin{array}{r}\text { Perceived } \\
\text { privacy }\end{array}$ & $\begin{array}{r}\text { Perceived } \\
\text { security }\end{array}$ & $\begin{array}{r}\text { Govern } \\
\text { ment } \\
\text { support }\end{array}$ & $\begin{array}{r}\text { Use of } \\
\text { e- } \\
\text { banking }\end{array}$ \\
\hline $\begin{array}{l}\text { Quality of } \\
\text { information }\end{array}$ & 0.953 & & & & & & & & \\
\hline Trust & 0.896 & 0.964 & & & & & & & \\
\hline $\begin{array}{l}\text { Performance } \\
\text { expectancy }\end{array}$ & 0.844 & 0.854 & 0.937 & & & & & & \\
\hline Effort expectancy & 0.836 & 0.849 & 0.885 & 0.965 & & & & & \\
\hline $\begin{array}{l}\text { Intention to use e- } \\
\text { banking }\end{array}$ & 0.812 & 0.816 & 0.868 & 0.779 & 0.965 & & & & \\
\hline Perceived privacy & 0.669 & 0.693 & 0.635 & 0.603 & 0.615 & 0.872 & & & \\
\hline Perceived security & 0.869 & 0.887 & 0.788 & 0.773 & 0.759 & 0.737 & 0.925 & & \\
\hline $\begin{array}{l}\text { Government } \\
\text { support }\end{array}$ & 0.230 & 0.217 & 0.253 & 0.251 & 0.234 & 0.237 & 0.247 & 0.924 & \\
\hline Use of e-banking & 0.352 & 0.375 & 0.360 & 0.350 & 0.414 & 0.256 & 0.325 & 0.006 & 1.000 \\
\hline
\end{tabular}

Table 5

Summary of the validity of the structural model

\begin{tabular}{|c|c|c|c|c|c|c|c|}
\hline \multicolumn{2}{|c|}{ Hypothesis } & Effect & $\begin{array}{l}\text { Original } \\
\text { Sample }(O)^{*}\end{array}$ & R squared & $\begin{array}{l}\text { Standard } \\
\text { Deviation } \\
\text { (STDEV) }\end{array}$ & $\begin{array}{l}\text { T Statistics } \\
\text { (|O/STDEV) }\end{array}$ & $\begin{array}{l}\mathrm{P} \\
\text { Values }\end{array}$ \\
\hline $\mathrm{H} 1$ & Accept & effort expectancy - > intention to use e-banking & $-0.182^{*}$ & \multirow{3}{*}{$\begin{array}{l}\text { Intention to } \\
\text { use e- } \\
\text { banking } \\
\mathrm{R}=0.774\end{array}$} & 0.057 & 1,941 & 0.050 \\
\hline $\mathrm{H} 2$ & Accept & $\begin{array}{l}\text { performance expectancy - >intention to use e- } \\
\text { banking }\end{array}$ & $0.679 * *$ & & 0.074 & 9.215 & 0.000 \\
\hline $\mathrm{H} 3$ & Reject & government support - > intention to use e-banking & 0.019 & & 0.019 & 0.984 & 0.325 \\
\hline $\mathrm{H} 4$ & Accept & trust -> intention to use e-banking & $0.301 * *$ & \multirow{2}{*}{$\begin{array}{l}\text { Trust: } \\
\mathrm{R}=0.853\end{array}$} & 0.061 & 4,978 & 0.000 \\
\hline H5 & Accept & trust -> use of e-banking & $0.181 *$ & & 0.065 & 1,936 & 0.017 \\
\hline $\mathrm{H} 6$ & Accept & quality of information - > trust & $0.506 *$ & \multirow{4}{*}{$\begin{array}{l}\text { Use of e- } \\
\text { banking } \\
R=0.215\end{array}$} & 0.063 & 7,965 & 0.000 \\
\hline $\mathrm{H} 7$ & Reject & perceived privacy -> trust & 0.054 & & 0.030 & 1,819 & 0.069 \\
\hline $\mathrm{H} 8$ & Accept & perceived security $->$ trust & $0.408 * *$ & & 0.058 & 7,082 & 0.000 \\
\hline $\mathrm{H} 9$ & Accept & intention to use e-banking - > use of e-banking & $0.326 * *$ & & 0.063 & 5.168 & 0.000 \\
\hline
\end{tabular}

Notes: Significant at: ${ }^{*} p<0,05$ t-value 1,$960 ;{ }^{* *} p<0,01$, t-value 2,576 
Figure 1. Proposed model

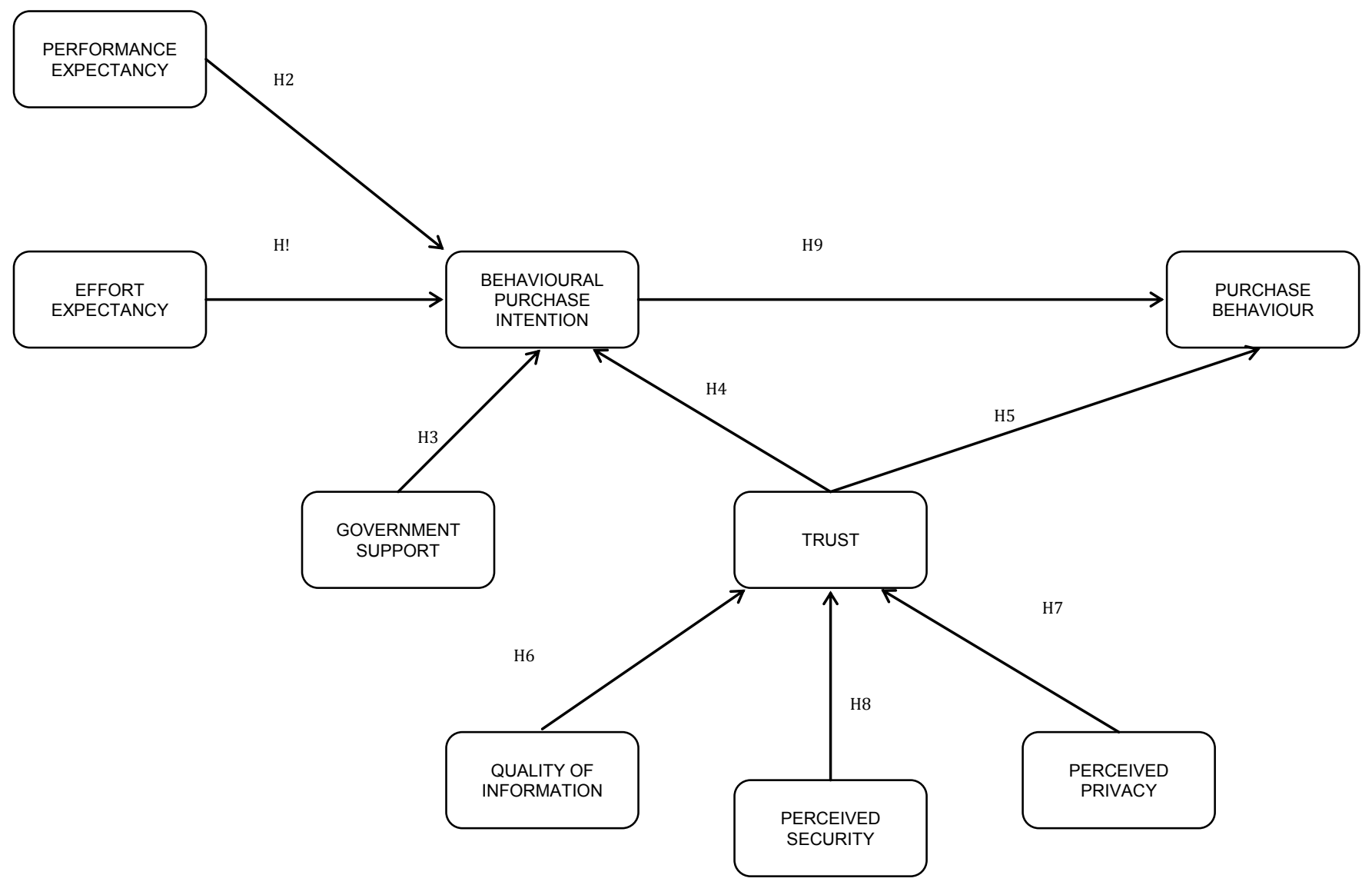


Figure 2. Validation of the model

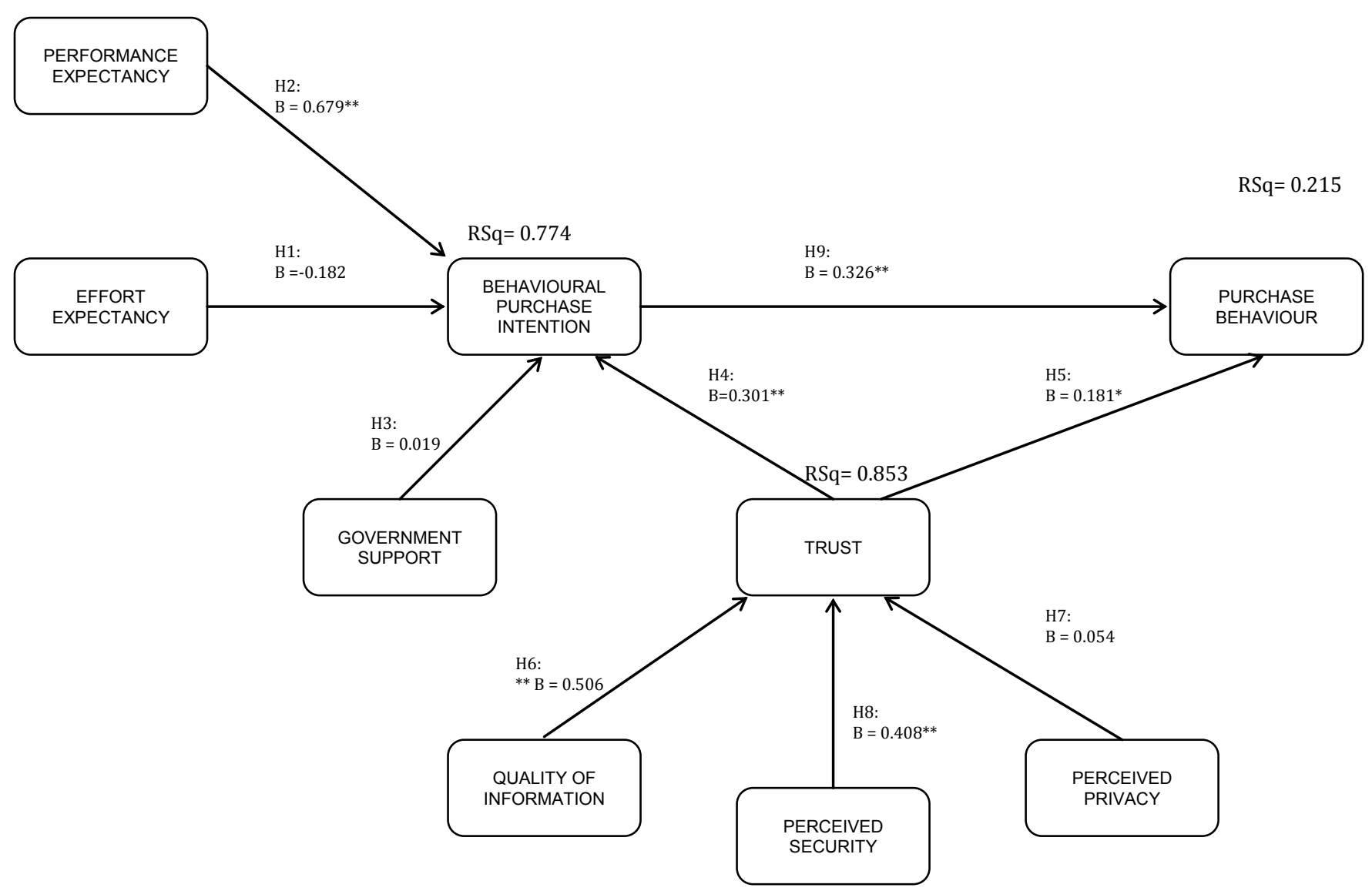

